\title{
Effects of spermine and putrescine polyamines on capsaicin accumula- tion in Capsicum annuum L. cell suspension cultures
}

\author{
Esra KOÇ ${ }^{1,2}$, Cemil İşLEK ${ }^{3}$, Belgizar KARAYİĞİT ${ }^{1}$
}

Effects of spermine and putrescine polyamines on capsaicin accumulation in Capsicum annuum L. cell suspension cultures

Abstract: This study examined the effects of different concentrations of spermine (Spm) and putrescine (Put) elicitors on capsaicin production at different times in cell suspension culture of peper (Capsicum annuum L'Kahramanmaraș Hat-187'.), raised from pepper seeds. Callus was obtained from hypocotyl explants of pepper seedlings germinated in vitro conditions, and cell suspensions were prepared from calluses. $\operatorname{Spm}(0.1,0.2$ and $\left.0.4 \mathrm{mg} \mathrm{l}^{-1}\right)$ and Put (0.1, 0.2 and $\left.0.4 \mathrm{mg} \mathrm{l}^{-1}\right)$ elicitors were applied on cell suspensions, and control groups free from elicitor treatment were created. The amount of capsaicin in cells was found to be higher in the control groups and samples treated with Spm elicitors when compared to filtrates. The highest increase in the capsaicin amount in cells was determined on day 12 of elicitation with $0.2 \mathrm{mg} \mathrm{l}^{-1} \mathrm{Spm}$ application. The highest capsaicin amount passing into the filtrate was determined as $0.1 \mathrm{mg} \mathrm{l}^{-1} \mathrm{Spm}$ on day 8 . The most effective Put concentration and time on capsaicin amount were found as $0.2 \mathrm{mg} \mathrm{l}^{-1} \mathrm{Put}$ on day 12 in both cells and filtrates. The highest total capsaicin was also determined in the $0.2 \mathrm{mg} \mathrm{l}^{-1} \mathrm{Spm}$ application on day 12 with $312.747 \pm 8.70 \mu \mathrm{g} \mathrm{g}^{-1}$ of culture. Exogenous treatment of Spm and Put elicitors affected capsaicin accumulation.

Key words: capsaicin; Capsicum annuum L.; cell filtrate; pepper; polyamines
Received June 25, 2019; accepted April 11, 2020. Delo je prispelo 25. junija 2019, sprejeto 11. aprila 2020
Učinki poliaminov spermina in putrescina na akumulacijo kapsaicina v suspenzijski kulturi celic paprike Capsicum annuum L.

Izvleček: $\mathrm{V}$ raziskavi so bili preučevani učinki različnih koncentracij spermina (Spm) in putrescina (Put) kot elicitorjev na tvorbo kapsaicina $\mathrm{v}$ različnih časovnih intervalih $\mathrm{v}$ suspenzijski celični kulturi paprike (Capsicum annuum 'Kahramanmaraş Hat-187'. Kalus je bil pridobljen iz izsečkov hipokotila kalic paprike, ki je vzkalila $\mathrm{v}$ in vitro razmerah, celične suspenzije so bile pripravljene iz kalusov. Spm $\left(0,1 ; 0,2\right.$ in $\left.0,4 \mathrm{mg} \mathrm{l}^{-1}\right)$ in Put $\left(0,1 ; 0,2\right.$ in $\left.0,4 \mathrm{mg} \mathrm{l}^{-1}\right)$ sta bila dodajana kor elicitorja $\mathrm{v}$ celične suspenzije, hkrati so bile vzpostavljene kontrolne celične kulture brez elicitorjev. Količina kapsaicina v celicah je bila večja $\mathrm{v}$ kontrolnih skupinah in vzorcih tretiranih celic $\mathrm{z}$ elicitorjem Spm kot pa v filtratu. Največje povečanje kapsaicina v celicah je bilo določeno po 12 dneh elicitacije $\mathrm{z}$ dodatkom $0,2 \mathrm{mg} \mathrm{l}^{-1} \mathrm{Spm}$. Največja količina kapsaicina $\mathrm{v}$ filtratu je bila določena osmi dan pri dodajanju $0,1 \mathrm{mg} \mathrm{l}^{-1} \mathrm{Spm}$. Najbolj učinkovita koncentracija Put, 0,2 $\mathrm{mg} \mathrm{l}^{-1}$, za tvorbo kapsaicina je bila 12 dni po dodajanju, $\mathrm{v}$ celicah kot v filtratu. Največja celokupna vsebnost kapsaicina, $312,747 \pm 8.70 \mu \mathrm{g} \mathrm{g}^{-1}$ kulture, je bila določena pri dodajanju 0,2 $\mathrm{mg} \mathrm{l}^{-1} \mathrm{Spm}$ na dvanajsti dan. Zaključimo lahko, da je dodajanje Spm in Put kot elicitorjev vplivalo na akumulacijo kapsaicina.

Ključne besede: kapsaicin; Capsicum annuum L.; celični filtrat; paprika; poliamini

1 Ankara University, Faculty of Sciences, Department of Biology, 06100, Ankara, Turkey

2 Corresponding author, e-mail: ekoc@science.ankara.edu.tr

3 Niğde Ömer Halisdemir University, Faculty of Sciences, Department of Biotechnology, Niğde, Turkey 


\section{INTRODUCTION}

Capsaicin is one of the most important alkaloids obtained from pepper plant, and it is used as a food additive due to its bitter aroma. It is used in the preparation of pharmacological compounds and in the treatment of rheumatic diseases as well. At the same time, the tonic and carmine form of Capsicum preparations are used for indigestion (Ramachandra Rao \& Ravishankar, 2002; Barbero et al., 2008; Hayman \& Kam, 2008). It takes 4-5 months to grow the pepper plant to be used for the production of capsaicin under normal conditions and therefore a continuous production process of capsaicin can be carried out over a long period of time and for a limited period of time. Continuous growth of pepper free cell cultures under in vitro conditions is a way to provide continuity for capsaicin production. Application of stabilized culturing systems and changing the environmental factors in order to increase the secondary metabolite compounds is accepted as a more efficient and newer method than suspension culturing system. When externally applied chemical elicitors are removed from callus and suspension culture cells, the amount of secondary metabolite compounds synthesized by the cells is also reduced. Therefore, methods have been developed to increase the synthesis of secondary metabolite compounds. Generally, the variety and amount of hormones applied to the culture medium are determinative on the amount of product synthesized (Lindsey, 1985). Two different compounds; salicylic acid and methyl jasmonate were applied separately and together to the suspension cultures of Capsicum frutescens L. cells (Sudha \& Ravishankar, 2003b) and both compounds were found to increase capsaicin synthesis and accumulation in culture cells. But, only salicylic acid increased the activity of capsaicin synthase enzyme, while methyl jasmonate compound had no effect on enzyme activity. According to these results, it can be concluded that increasing effect of methyl jasmonate on capsaicin concentration is due to its activity preventing capsaicin degradation or conjugation with other molecules. In addition, polyamine production of the cells increased with salicylic acid application and decreased with the application of methyl jasmonate (Sudha \& Ravishankar, 2003b).

Putrescine (Put), spermidine (Spd) and spermine (Spm) polyamines are low molecular mass substances present in all living organisms (Vuosku et al., 2018). Polyamines and their biosynthetic enzymes are involved in a wide range of metabolic events ranging from protecting plants against stress to cell organogenesis (Kaur-Sawhney et al., 2003; Puyang et al., 2015). When applied to plants alone, polyamines can be effective in many physiological events such as aging, embryogenesis, root growth, flow- ering, cell division, nucleic acid and protein synthesis and germination (Chen et al., 2018). Elicitation can be an important strategy to improve in vitro production of plant secondary metabolites. It has been previously demonstrated that in cell and organ cultures, biotic and abiotic elicitors have effectively stimulated production of almost all chemical classes of plant secondary metabolites (Brooks et al., 1986; Ramirez et al., 2016). The studies on secondary metabolite production by exogenous polyamine application are insufficient in tissue culture studies. Thus, the aim of this study was to prepare cell suspension cultures from hypocotyl explants of 'KahramanmaraşHat 187' (Capsicum annuum L.) pepper seedlings and add different concentrations of Spm and Put into them and the amount of capsaicin accumulating in the samples received from cell suspension cultures (cell+filtrate) were determined. Also, an attempt was made to determine the most effective elicitor concentration and time of application on capsaicin accumulation.

\section{MATERIAL AND METHOD}

\subsection{PLANT MATERIAL}

Pepper (Capsicum annuum 'KahramanmaraşHat 187') seeds used in the study were provided from Kahramanmaraş Agricultural Research Institute (Turkey).

\subsection{STERILIZATION OF SEEDS AND GERMINA- TION}

Pepper (Capsicum annuum L.) seeds used in the study were subjected to surface sterilization before sowing to sterile medium in sterile magenta box. They were dipped into $70 \%$ ethyl alcohol for three minutes and then sterilized with commercial $6 \%$ sodium hypochlorite for 30 minutes followed by washing with sterile distilled water in the sterile cabin. Sterilized pepper seeds were placed into each one of Magenta box containing about $50 \mathrm{ml}$ hormone-free Murashige \& Skoog (1962) (MS) sterile basic nutrient medium, and the caps of flasks where seeds were germinated were closed and covered by stretch film (Ellialtığlu et al., 1998).

\subsection{CULTURE CONDITIONS}

Pepper seedlings were germinated in the Murashige \& Skoog's (MS) medium (Murashige \& Skoog, 1962) without hormone and were used as explant source after 
completing the four week incubation period under sterile conditions in magenta containers in the growth chamber which was adjusted to 16 hours light $\left(27 \mu \mathrm{mol} \mathrm{m}{ }^{-2} \mathrm{~s}^{-1}\right)$ and 8 hours dark photoperiodic order (Figure 1). MS medium containing $1.0 \mathrm{mg} \mathrm{l}^{-1} 2,4$-dichlorophenoxyacetic acid (2,4-D) $0.1 \mathrm{mg} \mathrm{l}^{-1}$ kinetin, $3 \%$ sucrose and $0.7 \%$ agar was used in order to obtain callus from hypocotyl explants. After adjusting the $\mathrm{pH}$ of the MS medium to 5.7 and sterilizing that at autoclave, hypocotyl explants were placed horizontally on the medium. The developing callus tissues were taken as subculture into MS nutrient medium containing $1.0 \mathrm{mg} \mathrm{l}^{-1}$ 2,4-D, $0.1 \mathrm{mg} \mathrm{l}^{-1}$ kinetin, $3 \%$ sucrose and $0.7 \%$ agar. Callus tissues in magenta boxes were developed at the same photoperiodic order in the growth chamber (Figure 1).

\subsection{CELL SUSPENSION CULTURE}

MS nutrient medium including $1.0 \mathrm{mg} \mathrm{l}^{-1} 2,4-\mathrm{D}$ with $0.1 \mathrm{mg} \mathrm{l}^{-1}$ kinetin and $3 \%$ saccharose that was used for callus development were used also in the suspension culture, only agar was not added to the medium. $2 \mathrm{~g}$ callus tissues was added to each $100 \mathrm{ml}$ erlenmeyer flasks containing $40 \mathrm{ml}$ liquid nutrient medium. Erlenmeyer flasks containing the cell suspensions were incubated on a shaker at $100 \mathrm{rpm}$ and $25^{\circ} \mathrm{C}$ (Ellialtıoğlu et al., 1998).

\subsection{ELICITOR APPLICATIONS}

Cell suspension cultures developed for 30 days were transferred to the new nutrient medium, after which elicitor applications were performed and putrescine and spermine were used as elicitor. Trials were repeated in triplicate. Put $\left(0.1,0.2,0.4 \mathrm{mg} \mathrm{l}^{-1}\right)$ and $\operatorname{Spm}(0.1,0.2$, $0.4 \mathrm{mg} \mathrm{l}^{-1}$ ) were added as elicitors into $100 \mathrm{ml}$ erlenmayers containing cells and $40 \mathrm{ml}$ suspension culture in the sterile flask by means of a sterile micropipette. Sterile distilled water was used for control samples. Following the elicitor treatments, suspension cultures placed on a shakers at $25^{\circ} \mathrm{C}$ were subjected to the vacuum filtration process by means of a Buchner funnel vacuum pump over Whatman no.2 filter paper to separate the cell and its liquid phase after 8,10 and $12^{\text {th }}$ day, and cells and liquid phase samples parts were separated. Samples were stored at $-70^{\circ} \mathrm{C}$ until further processing.

\subsection{CAPSAICIN EXTRACTION}

For capsaicin extraction, $0.1 \mathrm{~g}$ cells were received and grinded using a mortar in $8 \mathrm{ml}$ ethyl acetate three times. They were then centrifuged at $3000 \mathrm{rpm}$ for 10 minutes and the supernatants on the surface were collected. The collected supernatants were evaporated at $55^{\circ} \mathrm{C}$ temperature at $180 \mathrm{rpm}$ under low pressure by using rotary evaporator by ensuring that the ethyl acetate part remained almost dry. The residue was dissolved in $1 \mathrm{ml}$ ethyl acetate and taken into labelled sample bottles. Samples were stored in the deep freezer at $-70{ }^{\circ} \mathrm{C}$ until they were analysed (Johnson et al., 1990).

\subsection{CAPSAICIN ANALYSIS FROM EXTRACTS}

Determination of capsaicin was conducted in accordance with Palacio method (1977, 1979). Accordingly, $1 \mathrm{ml}$ ethyl acetate was added to $200 \mu \mathrm{l}$ sample and $0.1 \mathrm{ml}$ of $5 \% \mathrm{VOCl}_{3}$ were added before measuring on the spectrophotometer. Measurement was carried out quickly after addition of $\mathrm{VOCl}_{3}$ to prevent color loss.

\subsection{STATISTICAL ANALYSIS}

The trials were organized to create an experimental design with 3 repetitions in randomized blocks. Data presented are mean values \pm standard deviation of measurement for 3 replicates. The datas were evaluated with
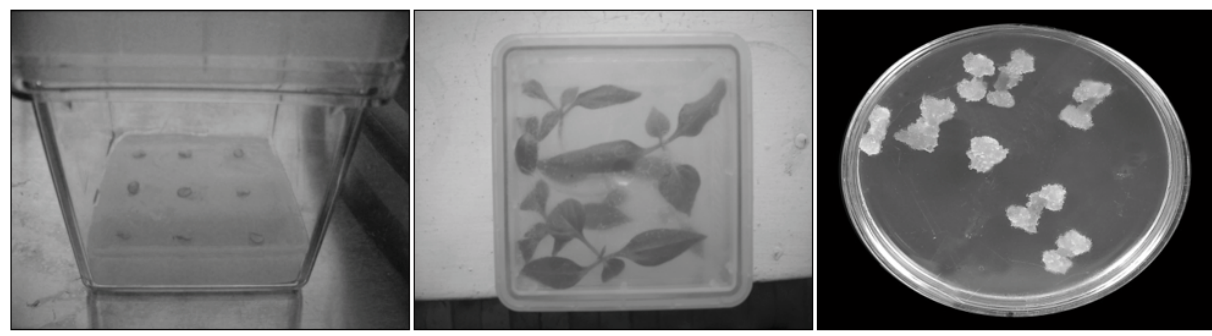

Figure 1: Seeding of pepper seeds in hormone-free MS basic nutrient medium and pepper seedlings in MS basic nutrient medium and callus tissues developing from hypocotyl explant 
repeated measures variance analysis technique in factorial order using SPSS 24.0 package program. The alpha level was set at $5 \%$.

\section{RESULTS AND DISCUSSION}

\subsection{THE EFFECT OF SPM ON ACCUMULATION OF CAPSAICIN}

In cells, it was determined that the amount of capsaicin increased in all other applications and days when compared with the control groups except for the application of $0.1 \mathrm{mg} \mathrm{l}^{-1} \mathrm{Spm}$ on day 8 . When compared with the control group, the maximum increase was observed on day 12 in the 0.1 and $0.2 \mathrm{mg} \mathrm{l}^{-1} \mathrm{Spm}$ applications: the increases in their values were approximately $200 \%$ and $295 \%$, respectively (Table 1.). When all applications and days were compared, the highest capsaicin amount was determined on day 12 in the $0.2 \mathrm{mg} \mathrm{l}^{-1} \mathrm{Spm}$ application in cells $(p<0.05)$. This capsaicin amount composed about $90 \%$ of total capsaicin (Table 1.).

The amount of capsaicin passing from cells to filtrate except for $0.4 \mathrm{mg} \mathrm{l}^{-1} \mathrm{Spm}$ application on day 12 increased when compared to the control group in all Spm applications while the highest capsaicin amount was determined in $0.1 \mathrm{mg} \mathrm{l}^{-1} \mathrm{Spm}$ application on day 8. Compared to control, the increase in its values was approximately $150 \%$ $(p<0.05)$. The lowest capsaicin amount was determined as $15.359 \pm 1.52 \mu \mathrm{g} 40 \mathrm{ml}^{-1}$ culture medium in $0.4 \mathrm{mg} \mathrm{l}^{-1}$ Spm application on day $12(p<0.05)$ (Table 1).

The highest total capsaicin was determined in the $0.2 \mathrm{mg} \mathrm{l}^{-1} \mathrm{Spm}$ application on day12 with approximately $312.747 \pm 8.70 \mu \mathrm{g} \mathrm{g}^{-1}$ of culture (Table 1). Except $0.4 \mathrm{mg} \mathrm{l}^{-1} \mathrm{Spm}$ application on day 12, compared to control, all applications increased the total capsaicin amount $(p<0.05)$. This result shows that the application of high concentrations of Spm for a long time may have a stress effect on the cells. The findings showed that the Spm increased the accumulation of capsaicin (Table 1).

\subsection{THE EFFECT OF PUT ON CAPSAICIN ACCU- MULATION}

In cells, the highest capsaicin amount on days 8,10 , 12 was determined in control groups. Compared to the control group, all of the elicitor concentrations caused a decrease in the amount of capsaicin $(p<0.05)$ (Table 2.). When all Put applications and days were compared, the maximum capsaicin amount was determined as 37.84 $\pm 2.53 \mu \mathrm{g} \mathrm{g}^{-1} \mathrm{fm}$ in the $0.2 \mathrm{mg} \mathrm{l}^{-1}$ Put application on day 8 and as $36.49 \pm 3.11 \mu \mathrm{g} \mathrm{g}^{-1} \mathrm{fm}$ on day 12 . The lowest amount of capsaicin was found in the $0.1 \mathrm{mg} \mathrm{l}^{-1}$ Put concentration on days 8 and $10(p<0.05)$ (Table 2$)$.

Compared to the control group, all of the Put concentrations caused an increase in the amount of capsaicin in filtrate of cells $(p<0.05)$ (Table 2). The highest amount of capsaicin in the filtrate was determined as

Table 1: Effect of Spm application on capsaicin accumulation in cells and filtrate of C. annuum 'KM-187' at different concentrations and days. The data represent the mean of three replications and error bars indicate SD

\begin{tabular}{|c|c|c|c|c|}
\hline \multirow[b]{2}{*}{ Days } & \multirow[b]{2}{*}{ Applications } & \multicolumn{3}{|c|}{ Capsaicin } \\
\hline & & $\begin{array}{l}\text { Cell } \\
\left(\mu \mathrm{g} \mathrm{g}^{-1} \mathrm{fm}\right)\end{array}$ & $\begin{array}{l}\text { Filtrate } \\
\left(\mu \mathrm{g} 40 \mathrm{ml}^{-1}\right. \\
\text { culture medium) }\end{array}$ & $\begin{array}{l}\text { Total (culture) } \\
\left(\mu \mathrm{g} \mathrm{g}^{-1}\right)\end{array}$ \\
\hline \multirow[t]{4}{*}{8} & Control & $70.204 \pm 3.590$ & $22.361 \pm 1.925$ & $92.563 \pm 5.015$ \\
\hline & $0.1 \mathrm{mg} \mathrm{l}^{-1} \mathrm{Spm}$ & $40.079 \pm 2.102$ & $50.951 \pm 7.411$ & $91.030 \pm 5.588$ \\
\hline & $0.2 \mathrm{mg} \mathrm{l}^{-1} \mathrm{Spm}$ & $89.709 \pm 5.457$ & $28.535 \pm 3.309$ & $118.242 \pm 6.758$ \\
\hline & $0.4 \mathrm{mg} \mathrm{l}^{-1} \mathrm{Spm}$ & $97.991 \pm 4.880$ & $31.703 \pm 3.022$ & $129.695 \pm 7.757$ \\
\hline \multirow[t]{4}{*}{10} & Control & $63.767 \pm 1.748$ & $29.406 \pm 2.595$ & $93.171 \pm 1.017$ \\
\hline & $0.1 \mathrm{mg} \mathrm{l}^{-1} \mathrm{Spm}$ & $89.943 \pm 1.403$ & $29.024 \pm 1.996$ & $118.966 \pm 0.334$ \\
\hline & $0.2 \mathrm{mg} \mathrm{l}^{-1} \mathrm{Spm}$ & $67.668 \pm 2.026$ & $33.970 \pm 4.158$ & $101.637 \pm 6.081$ \\
\hline & $0.4 \mathrm{mg} \mathrm{l}^{-1} \mathrm{Spm}$ & $145.898 \pm 6.336$ & $37.667 \pm 6.124$ & $183.695 \pm 7.696$ \\
\hline \multirow[t]{4}{*}{12} & Control & $71.966 \pm 2.428$ & $25.883 \pm 1.683$ & $97.849 \pm 2.959$ \\
\hline & $0.1 \mathrm{mg} \mathrm{l}^{-1} \mathrm{Spm}$ & $214.306 \pm 3.423$ & $32.810 \pm 2.541$ & $247.116 \pm 5.951$ \\
\hline & $0.2 \mathrm{mg} \mathrm{l}^{-1} \mathrm{Spm}$ & $281.824 \pm 7.397$ & $30.930 \pm 2.934$ & $312.747 \pm 8.70^{*}$ \\
\hline & $0.4 \mathrm{mg} \mathrm{l}^{-1} \mathrm{Spm}$ & $73.082 \pm 2.676$ & $15.359 \pm 1.524$ & $88.442 \pm 4.191$ \\
\hline
\end{tabular}


Table 2: Effect of Put application on capsaicin amount in cells and filtrate of C. annuum 'KM-187' at different concentrations and days. The data represent the mean of three replications and error bars indicate $\mathrm{SD}(\mathrm{n}=3)$

\begin{tabular}{|c|c|c|c|c|}
\hline \multirow[b]{2}{*}{ Days } & \multirow[b]{2}{*}{ Applications } & \multicolumn{3}{|c|}{ Capsaicin } \\
\hline & & $\begin{array}{l}\text { Cell } \\
\left(\mu \mathrm{g} \mathrm{g}^{-1} \mathrm{fm}\right)\end{array}$ & $\begin{array}{l}\text { Filtrate } \\
\left(\mu \mathrm{g} 40 \mathrm{ml}^{-1}\right. \\
\text { culture medium) }\end{array}$ & $\begin{array}{l}\text { Total (culture) } \\
\left(\mu \mathrm{g} \mathrm{g}^{-1}\right)\end{array}$ \\
\hline \multirow[t]{4}{*}{8} & Control & $40.004 \pm 1.313$ & $15.094 \pm 1.824$ & $54.098 \pm 0.963$ \\
\hline & $0.1 \mathrm{mg} \mathrm{l}^{-1}$ Put & $12.636 \pm 2.171$ & $15.545 \pm 2.490$ & $28.181 \pm 5.048$ \\
\hline & $0.2 \mathrm{mg} \mathrm{l}^{-1}$ Put & $37.845 \pm 2.538$ & $32.147 \pm 3.309$ & $69.992 \pm 8.092$ \\
\hline & $0.4 \mathrm{mg} \mathrm{l}^{-1}$ Put & $20.820 \pm 2.935$ & $23.928 \pm 3.863$ & $44.495 \pm 6.217$ \\
\hline \multirow[t]{4}{*}{10} & Control & $43.492 \pm 0.660$ & $16.950 \pm 3.635$ & $60.442 \pm 3.750$ \\
\hline & $0.1 \mathrm{mg} \mathrm{l}^{-1}$ Put & $11.720 \pm 2.163$ & $26.479 \pm 4.863$ & $38.199 \pm 5.829$ \\
\hline & $0.2 \mathrm{mg} \mathrm{l}^{-1}$ Put & $31.163 \pm 5.230$ & $37.263 \pm 4.420$ & $68.426 \pm 8.850$ \\
\hline & $0.4 \mathrm{mg} \mathrm{l}^{-1}$ Put & $18.136 \pm 0.181$ & $31.883 \pm 4.450$ & $50.020 \pm 4.435$ \\
\hline \multirow[t]{4}{*}{12} & Control & $44.740 \pm 1.094$ & $16.540 \pm 0.487$ & $61.280 \pm 0.655$ \\
\hline & $0.1 \mathrm{mg} \mathrm{l}^{-1}$ Put & $15.586 \pm 0.583$ & $20.536 \pm 5.334$ & $36.122 \pm 5.916$ \\
\hline & $0.2 \mathrm{mg} \mathrm{l}^{-1}$ Put & $36.491 \pm 3.110$ & $44.287 \pm 1.972$ & $80.784 \pm 4.97^{\star}$ \\
\hline & $0.4 \mathrm{mg} \mathrm{l}^{-1} \mathrm{Put}$ & $23.244 \pm 0.520$ & $29.178 \pm 3.308$ & $52.422 \pm 3.024$ \\
\hline
\end{tabular}

$44.29 \pm 1.97 \mu \mathrm{g} \mathrm{g}^{-1} \mathrm{fm}$ in the $0.2 \mathrm{mg} \mathrm{l}^{-1}$ Put concentration on day 12; compared to control, the increase in value was $173 \%(p<0.05)$. This capsaicin amount composed about $54.8 \%$ of total capsaicin $\left(80.784 \pm 4.97 \mu \mathrm{g} \mathrm{g}^{-1}\right.$ of culture).The lowest amount of capsaicin was found in control groups $(p<0.05)$ (Table 2). In filtrate of cells, the most effective elicitation concentration and time were 0.2 $\mathrm{mg} \mathrm{l}^{-1}$. Put and on day 12 , respectively. The highest total capsaicin was determined in the $0.2 \mathrm{mg} \mathrm{l}^{-1}$ Put application on day 12 with $80.784 \pm 4.97 \mu \mathrm{g} \mathrm{g}^{-1}$ of culture (Table 2).

\section{DISCUSSION}

Capsaicin biosynthesis takes place through two metabolic pathways as phenylpropanoid pathway and valine metabolic pathway. The first part of the aromatic biosynthesis pathway is commonly shared with the phenylpropanoid metabolism in all plants. This suggests that the exogenous elicitor treatment might forward the metabolic pathway in this direction. The elicitation of secondary metabolites in plant cell cultures has been reported in the majority of plant types (Ramachandra Rao \& Ravishankar 2002). Increasing secondary plant metabolites enhances survival, permanence and competitiveness of a plant (Cheong \& Choi, 2003; Wasternack \& Hause et al., 2013). It is known that various biotic and abiotic elicitors increase the production of phytochemicals in culture cells several times (Zhao et al., 2005; Savitha et al., 2006; Namdeo, 2007; Baenas et al., 2014). The use of elicitors, which can induce the synthesis of these substances in tissues of different plant species under in vitro conditions, is considered as an alternative method. Elicitors are molecules that activate the signal transduction cascade and result in activation and expression of genes related to the biosynthesis of secondary metabolites (Zhao et al., 2005). Thus, various elicitors that might stimulate the synthesis of these substances in tissues of different plant types under in vitro conditions were addressed, and effective concentration and durations that need to pass after the treatment were determined. Elicitor concentration and induction time are accepted as key factors affecting cell growth and product yield for plant cell suspension culture (Wang et al., 2015). Studies have reported that different elicitors have different effects on capsaicin synthesis. The effect of polyamine compounds on capsaicin accumulation is another subject under investigation. In the study carried out in callus cultures of Pinus virginiana Mill. plant, high peroxidase (POX) activity and increase in callus development were determined in brown callus cultures with the addition of exogenous polyamine (Tang et al., 2004). An increase in the growth rate and synthesis of capsaicin was observed as a result of the application of $0.1 \mathrm{mmol} \mathrm{l}^{-1}$ Put to the suspension culture medium of Capsicum frutescens L. cells (Sudha \& Ravishankar, 2003a). In addition, it was found that capsaicin synthase activity increased in Put applied Capsicum frutescens cultures. Capsaicin synthase, a terminal enzyme of the capsaicin biosynthetic pathway, catalyses the condensation reaction between vanilyalamine and nonanoic acid 
to form capsaicin. It has been suggested that this increase in the amount of capsaicin results from an increase in the activity of capsaicin synthase. Also, Ahern et al. (2006) reported that Spm, Spd and Put are potential ligands for the capsaicin receptor TRPV1 and that they can regulate the activity of TRPV1 through the cationic charges of polyamines. They found that spermine at low concentrations could potentially increase activity and responses. In this study, we studied the production of capsaicin from the callus of Capsicum annuum. The findings obtained in our study show that Put elicitor was an increasing effect on capsaicin accumulation. The most effective Put concentration and application time on total capsaicin amount in C. annuum 'KM-187' cell suspension culture were determined as $0.2 \mathrm{mg} \mathrm{l}^{-1}$ and on day 12. Taking into account all application concentrations and days, the highest increase in total capsaicin amount was determined at $0.2 \mathrm{mg}^{-1} \mathrm{Spm}$ concentration on day 12 in the cell suspension culture (cell + filtrate). The amount of capsaicin in cells was found to be higher in the control groups and samples treated with Spm elicitors when compared to filtrates. The differences in the amount of capsaicin in the control groups for both elicitors may be due to cell suspensions initiated at different times. These results show that elicitor concentration and incubation time play a key role in the increase observed in the capsaicin amount. Therefore, both concentrations and incubation periods of elicitors should be optimized for a maximum elicitation of the capsaicin synthesis.

\section{CONCLUSION}

As a result of this study, it was found out that the capsaicin amount in cells in the Spm applications was more than in filtrates. The most effective concentration and application time for both elicitors was found to be $0.2 \mathrm{mg} \mathrm{l}^{-1}$ and on day 12 . These increases in the amount of capsaicin may be due to an increase in capsaicin synthase activity. More detailed studies are needed to put forward the mechanism behind the changes in capsaicin amount. This study showed that Spm and Put can be used to induce capsaicin accumulation in cultured plant cells. There is a need for screening a number of possible various elicitors for their effect on capsaicin synthesis before applying them in industrial scale.

\section{REFERENCES}

Ahern, G.P., Wang, X., Miyares, R.L. (2006). Polyamines are potent ligands for the capsaicin receptor TRPV1. The Jour- nal of Biological chemistry, 281(13), 8991-8995. https:// doi:10.1074/jbc.M513429200

Baenas, N., García-Viguera, C., Moreno, D.A. (2014). Elicitation: A tool for enriching the bioactive composition of foods. Molecules, 19, 13541-13563. https://doi:10.3390/ molecules190913541

Barbero, G.F., Liazid, A., Palma, M., Barroso, C.G. 2008. Ultrasound-assisted extraction of capsaicinoids from peppers. Talanta, 75, 1332-1337. https://doi.org/10.1016/j.talanta.2008.01.046

Brooks, C.J.W., Watson, D.G., Freer, I.M. (1986). Elicitation of capsidiol accumulation in suspended callus cultures of Capsicum annuum. Phytochemistry, 27(5), 1089-1092. https://doi.org/10.1016/S0031-9422(00)81559-9

Chen, D., Shao, Q., Yin, L., Younis, A.,Zheng, B. (2018). Polyamine function in plants: metabolism, regulation on development, and roles in abiotic stress responses. Frontiers Plant Science, 9, 1945. https://doi: 10.3389/fpls.2018.0194

Cheong, J.J., \& Do Choi, Y. (2003). Methyl Jasmonate as a vital substance in plants. Trends in Genetics, 19, 409-413. https:// doi.org/10.1016/S0168-9525(03)00138-0

Ellialtıoğlu, Ş., \& Üstün, A.S., Mehmetoğlu, Ü. (1998). Bazı biber çeşitlerinde in vitro kallus oluşumu için en uygun besin ortamı bileşiminin belirlenmesi. II-Kızılırmak Uluslararası Fen Kongresi (pp. 51-58). Kirıkkale.

Hayman, M., \& Kam, P. C. (2008). Capsaicin: a review of its pharmacology and clinical applications. Current Anaesthesia \& Critical Care, 19(5-6), 338-343. https://doi. org/10.1016/j.cacc.2008.07.003

Johnson, T.S., Ravishankar, G.A., Venkataraman, L.V. (1990). In vitro capsaicin production by immobilized cells and placental tissues of Capsicum annuum L. grown in liquid medium. Plant Science, 70(2), 223-229. https://doi.org/10.1016/01689452(90)90137-D

Kaur-Sawhney, R., Tiburcio, A.F., Altabella, T., Galston, A.W. (2003). Polyamines in plants: an overview. Journal of Cell and Molecular Biology, 2, 1-12.

Lindsey, K. (1985). Manipulation by nutrient limitation of the biosynthetic activity of immobilized cells of Capsicum frutescens Mill. cv. annuum. Planta, 165, 126-133. https:// doi:10.1007/BF00392221

Murashige, T., \& Skoog, F. (1962). A revised medium for rapid growth and bio-assays with tobacco tissue cultures. Physiologia Plantarum, 15, 473-497. https://doi. org/10.1111/j.1399-3054.1962.tb08052.x

Namdeo, A. (2007). Plant cell elicitation for production of secondary metabolites: a review. Pharmacognosy Reviews, 1, 69-79. http://www.phcogrev.com

Puyang, X., An, M., Han, L., Zhang, X. (2015). Protective effect of spermidine on salt stress induced oxidative damage in two Kentucky bluegrass (Poa pratensis L.) cultivars. Ecotoxicology and Environmental Safety, 117, 96-106. https:// doi10.1016/j.ecoenv.2015.03.023

Palacio, J.J.R. (1977). Spectrophotometric determination of capsaicin. Journal Association of Official Analytical Chemists, 60, 970-972. https://doi.org/10.1093/jaoac/60.4.970

Palacio, J.J.R. (1979). Further study of the spectrophotometric determination of capsaicin. Journal-Association of 
Official Analytical Chemists, 62, 1168-1170. https://doi. org/10.1093/jaoac/62.5.1168

Ramirez, E.K., Vidal, L.H., Hidalgo, D., Moyano, E., Golenioswki, M., Cusidó, R., Palazon, J. (2016). Elicitation, an effective strategy for the biotechnological production of bioactive high-added value compounds in plant cell factories. Molecules, 21(2), 182. https://doi:10.3390/molecules21020182

Ramachandra Rao, S., \& Ravishankar, G.A. (2002). Plant cell cultures: Chemical factories of secondary metabolites. Biotechnology Advances, 20, 101-153. https://doi.org/10.1016/ S0734-9750(02)00007-1

Savitha, B.C., Thimmaraju, R., Bhagyalakshmi, N., Ravishankar, G.A. (2006). Different biotic and abiotic elicitors influence betalain production in hairy root cultures of Beta vulgaris in shake-flask and bioreactor. Process Biochemistry, 41, 5060. https://doi.org/10.1016/j.procbio.2005.03.071

Sudha, G., \& Ravishankar, G. A. (2003a). Putrescine facilitated enhancement of capsaicin production in cell suspension cultures of Capsicum frutescens. Journal of Plant Physiology, 160, 339-346. https:// doi:10.1078/0176-1617-00928

Sudha, G., \& Ravishankar, G. A. (2003b). Influence of methyl jasmonate and salicylic acid in the enhancement of capsaicin production in cell suspension cultures of Capsicum frutescens Mill. Current Science, 85(8), 1212-1217. https:// www.jstor.org/stable/24108623
Tang, W., Harris, L.C., Outhavong, V., Newton, R.J. (2004). Antioxidants enhance in vitro plant regeneration by inhibiting the accumulation of peroxidase in Virginia pine (Pinus virginiana Mill.). Plant Cell Reports, 22(12), 871-877. https:// doi:10.1007/s00299-004-0781-3

Vuosku, J., Karppinen, K., Muilu-Mäkelä, R., Kusano, T., Sagor, G. H. M., Avia, K. (2018). Scots pine aminopropyltransferases shed new light on evolution of the polyamine biosynthesis pathway in seed plants. Annals of Botany, 121, 1243-1256. https://doi:10.1093/aob/mcy012

Zhao, J., Davis, L.C., Verpoorte, R. (2005). Elicitor signal production leading to production of plant secondary metabolites. Biotechnology Advances, 23, 283-333. https://doi. org/10.1016/j.biotechadv.2005.01.003

Wang, J., Qian, J., Yao, L., Lu, Y. (2015). Enhanced production of flavonoids by methyl jasmonate elicitation in cell suspension culture of Hypericum perforatum. Bioresources and Bioprocessing 2(1),5. https://doi: 10.1186/s40643-014-0033-5

Wasternack C. \& B. Hause . (2013). Jasmonates: biosynthesis, perception, signal transduction and action in plant stress response, growth and development. An update to the 2007 review in Annals of Botany. Annals Botany, 111(6), 10211058. https://doi.org/10.1093/aob/mct067 